\title{
OVERBANK SEDIMENTS ALONG THE MIDDLE WIEPRZA AS A RECORD OF FLOOD PHENOMENA
}

\author{
JACEK KACZMARZYK, WACŁAW FLOREK \\ Department of Geomorphology and Quaternary Geology, \\ Institute of Geograpghy and Regional Studies, Pomeranian University in Słupsk, \\ Partyzantów 27, 76-200 Słupsk, Poland \\ E-mails: kaczmarz@go2.pl; florekw@apsl.edu.pl
}

\begin{abstract}
Today's flood events along the River Wieprza assume a quite characteristic course entailing calm spillovers of water from the bed in places of riverbank lowering and in sections above and below bridges, where a narrowing of the channel is present. The identity of the land inundated relates to morphology, the near-channel part of a floodplain may be affected or those parts in depressions that serve as flood basins.

Riverbank exposures on both sides of the present river channel plus pits reveal the construction of the Wieprza floodplain. The sediments that build the floodplain represent channel and overbank facies with subfacies of palaeomeander fills. Analysed exposures are located along the valley section between Sławsko and Staniewice, mostly in close proximity to the Early Mediaeval fortified site of Wrześnica. The content of the exposures indicates that the uniform cover of overbank sediments across the floodplain emerged during the last 1000 years. It is now impossible to say when exactly, so it is unknown what the rank of the extreme floods which took place at the end of $19^{\text {th }}$ century was, and what their role in forming the present floodplain.
\end{abstract}

Key words: paleomeanders, Holocene, overbank deposits, flood, floodplain, Medieval fortified site, Wieprza river.

\section{INTRODUCTION}

The range of occurrence and lithological characteristics of overbank sediments are viewed as important indicators of the functioning of a river system, reflecting hydrological and physiographic characteristics, and the degree and nature of human interference in the catchment and channel environments. Recently observed extreme meteorological and hydrological events, commonly linked with global warming, cause high water to appear more frequently than in previous decades, this spilling over the banks of rivers flowing through the re- gion of Pomerania. The above explains the authors' interest in characteristics of contemporary overbank sediments, as well as the attempt made to compare them with sediments accumulated during the last millennium. In the opinion of the authors this provides for an assessment of the importance of contemporary hydrological phenomena, as set against changes taking place in the younger part of the Sub-Atlantic period.

The first phase to the investigations presented below was financed from the own funds of the Pomeranian Pedagogical Academy in Stupsk, while later financing has been from Grant PBZ-KBN-086/P04/2003 
"Extreme meteorological and hydrological events in Poland (assessment of events and evaluation of their impact on the human environment)", grant leader prof. dr hab. Jacek Jania - Department of Earth Sciences, Silesian University), Task 5.5.4. "Regularities to the progress of extreme events in valley-bottom areas" and Task 5.5.8 "Influence of extreme events on the functioning of geosystems of the Baltic coastal zone and of river valleys in near-coast areas".

Investigations were carried out along the bottom of the generally longitudinallyoriented glacial trough part of the Wieprza Valley. The lowest morphological level of the valley was formed from the beginning of the Holocene as the floodplain of the meandering river. This fact is borne out by the dating of organogenic sediments filling the oldest palaeomeanders (Florek 1991).

\section{HYDROLOGICAL CONDITIONS ALONG THE WIEPRZA, AND THEIR RELA- TIONSHIP WITH THE DEVELOPMENT OF OVERBANK SEDIMENT COVERS}

Analysis of Wieprza valley cross-sections at water level gauging stations, as based on morphometric data from the Institute of Meteorology and Water Management (IMWM), shows that these may not be treated as a source of information about the frequency and spatial extent of river floods. According to data for the profiles at the Sławno and Stary Kraków gauges, the highest observed water stages remain within the river channel, while observations made during the last six years, at water stages lower by $1-100 \mathrm{~cm}$, prove that even at such water stages a large part of the floodplain becomes inundated. If the periodic dredging of the bed, and the earlier described effects of river training (Florek and Nadaczna 1986, Florek 1991), are taken into account, it can be supposed that at discharges similar to the present maxima and with a gentler river slope, flooding in the floodplain must have been a quite frequent occurrence.

Contemporary high waters along the Wieprza, even those close to observed maximum stages, proceed in a characteristic way. Water overflows gently at places where the banks are low, and on stretches above and below bridges, where the river channel becomes narrower. Depending on morphology, it is either the floodplain close to the river that becomes inundated, or the depressions in the floodplain which serve as flood basins. Such a character of the high water along the Wieprza is decided by a set of environmental characteristics, which i.a. influence directly or indirectly the nature of the variability in water levels. The main characteristics of the Wieprza include:

- a pronounced (70-75\%) prevalence of subterranean supply over surface supply,

- a great abundance of water (mean specific discharge $9.7 \mathrm{l} / \mathrm{s} / \mathrm{m}^{2}$ ),

- a high degree of equalization of runoff year-round, as conditioned by climate and physiography,

- low amplitude of water stages (from about $0.5 \mathrm{~m}$ in the upper course to about $3 \mathrm{~m}$ along the lower Wieprza).

According to the classification from Dynowska (1971), the lower Wieprza catchment is among areas with a weakly developed nival type of river regime (type 1). Average discharge in a spring month does not exceed $130 \%$ of average monthly discharge. The upper Wieprza catchment is in an area of moderately-developed nival-type river regime (type 3 ), under which the average spring month discharge is $130-180 \%$ of average monthly discharge. The values for the coefficient of flow irregularity $\mathrm{Q}_{\max } / \mathrm{Q}_{\text {min }}$, calculated for the water level gauge at Stary Kraków (11.3) are very low, and characteristic for Pomeranian rivers (see Florek 1991); the values calculated for Sławno are even lower, but to a certain 
degree this results from a shorter period of observations there.

Floods along the Wieprza arise mainly in February and March (Biernat 1977a), or in April (Cyberski 1984). Low water occurs in all seasons except spring, though most often in June or in summer (Biernat 1977b). If the winter is very cold, then low water occurs in February.

Morphological effects of floods are above all visible in the zone directly adjacent to the river channel, in the form of sandy bars, sandy shadows, levees, point bars and sediments filling oxbow lakes. (Florek and Kaczmarzyk 2007). In areas close to such forms, which are within the reach of floodwaters, the sedimentation effect is minimal, taking the form of thin fine sand/mud covers, sometimes dark-tinted due to the presence of organic matter.

\section{THE RELATIONSHIP BETWEEN CHANNEL SEDIMENTS AND OVERBANK SEDIMENTS}

Outcrops on both banks of the contemporary river channel and pits excavated in the floodplain give a view of the structure of the flood horizon. Sediments building the floodplain represent river channel and overbank facies, with a subfacies of sediments filling the palaeomeanders. The analysed outcrops are located in the part of the valley between Sławsko and Staniewice, most of them in the vicinity of the Early Mediaeval fortified site called Wrześnica (Fig. 1). Archaeological and dendrological dates for these (end of $9^{\text {th }}$ century; Raczkowski and Sikorski 1996) provide an age premise for some of the analysed sediments from the outcrops.

The morphology of the part of the floodplain adjacent to the right bank of the river indicates that a bank outcrop $(37 \mathrm{~m}$ in length) has the river channel sediments of a palaeomeander circling the Early Me-

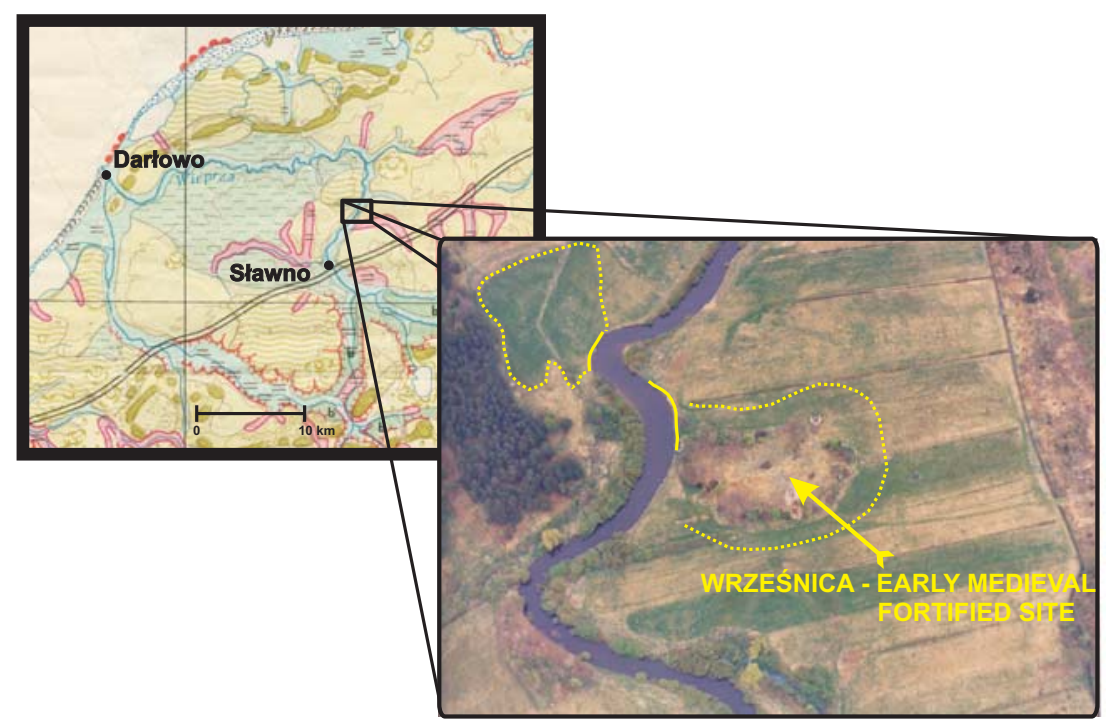

Figure 1. Location of the investigated river bank exposures. 

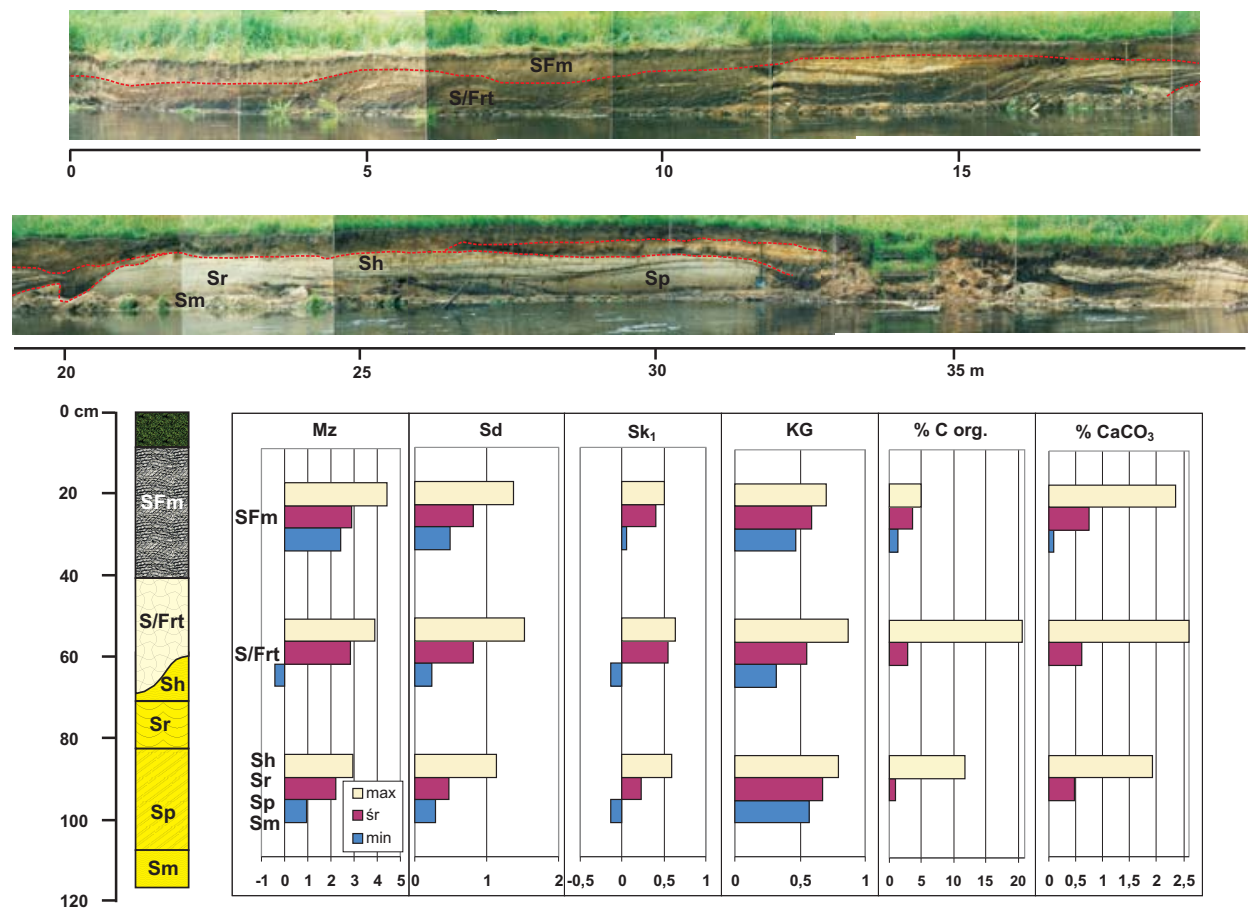

Figure 2. Exposure on the right river bank showing relationship between channel sediments, palaeomeander infilling and overbank deposit cover (explanations of the lithodynamic's code in the text).
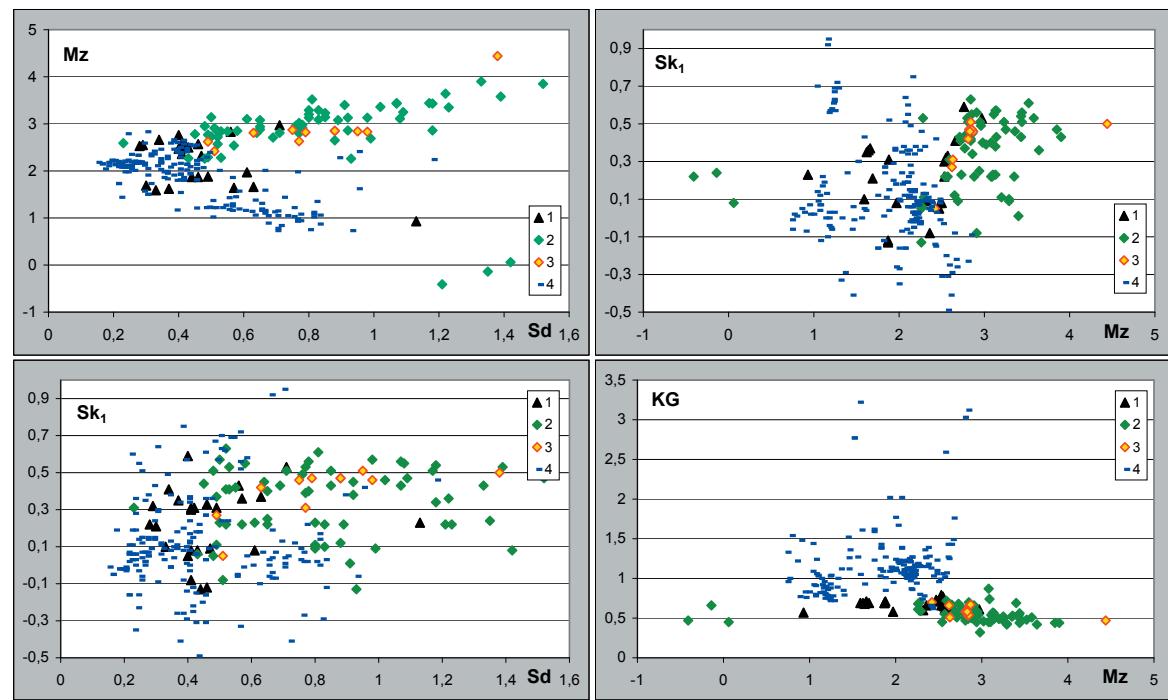

Figure 3. The relationship between different grain perimeters of the river deposits exposed on the right bank of the Wieprza; 1 - fossil channel deposits, 2 - palaeochannel infilling deposits, 3 - sub-fossil overbank (flood) deposits, 4 - contemporary sandy bars and sandy shadow deposits. 
dieval Wrześnica fortified site, sediments filling that palaeomeander and overbank sediments, which are the top part of the floodplain. The geomorphological situation accounts for significant variability in sediment thickness, and for the marked differentiation of layers in the horizon. The only continuous layer over the whole length of the outcrop is the layer of warp soil formation, formed as sandy mud.

Lithofacially, the river channel sediments visible in the structure and building a point bar are mainly fine sand with lenses and narrow interbeddings of organic mud. The sand is shaped in the form of lithofacies Sp (sand with flat diagonal bedding), $\mathrm{Sr}$ (sand with diagonal ripplemark lamination) and Sh (horizontally bedded sand); organic inserts form the Fm lithofacies. A similar lithofacial set was presented by Zieliński (1998). On the diversified surface of the meander point bar, and in its vicinity, there are palaeomeander fill sediments, which are in the form of lithofacies Fm (organic mud) and SFm (muddy sand) and series of rhythmites, for which Szmańda (2006) proposed the symbol S/Frt in connection with the lithofacial code of Miall (1978, 1985) and Zieliński (1995, 1998). This indicates a regularity, a rhythm (rhythmite $=\mathrm{rt}$ ) to the occurrence of thin sand (Sm) and mud (Fm) laminations of ca. $1 \mathrm{~cm}$ thickness and massive structure. Each pair of laminae (Sm, Fm) is connected with one flood and its two stages. The Sm is accumulated at the time of culmination, Fm during stabilisation and when the high water has passed. The Fm layer is more finely-grained and darker, due to decantation of the light organic particles transported in suspension. In the case of the oxbow lake partly filled with water, organic accumulation may still be in progress after the end of the flood, and may lead to growth in the thickness of the Fm (organic mud) layers. Such layers of flood sediments formed as rhythmites are characteristic, and have been described for various rivers, e.g. the Warta (Antczak 1986), Vistula (Mycielska-Dowgiałło, Zieliński 1997), Tążyna (Szmańda 2006), and others. The fossil overbank sediments of the Wieprza also show such regularities (Kaczmarzyk 2004).

Along the whole outcrop, the ceiling part of the floodplain is covered by a $20-40 \mathrm{~cm}$ thick layer of a warp soil formation in the form of SFm lithofacies (muddy sand of massive structure). The spatial reach of this layer indicates a similar reach of floodwater, which transports significant amounts of fine material in suspension. In a pit dug several metres from the present river bank, directly by the fortified site, the analysed layer rests on the remains of a timber road structure connected with this archaeological object (Fig. 4). This offers a significant premise in

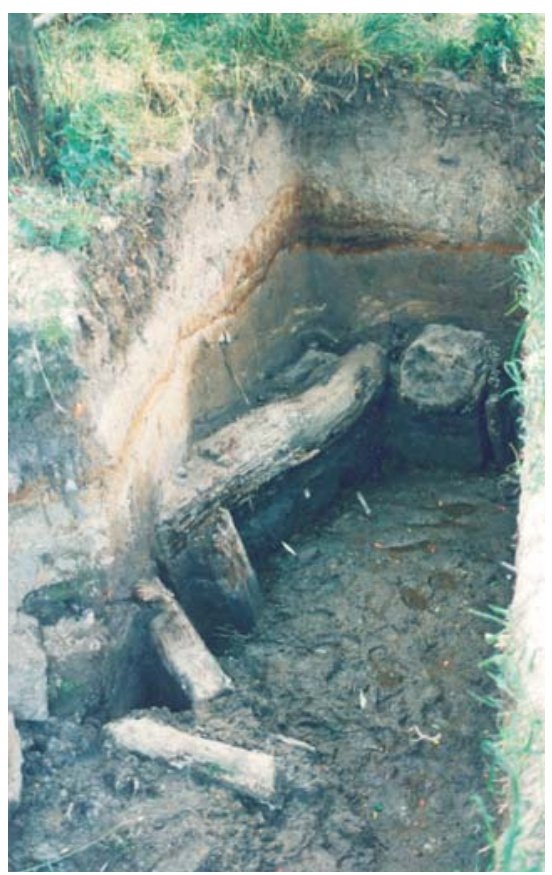

Figure 4. Wrześnica fortified site. Mediaeval woody constructions of road and jetty covered by mid-Sub-Atlantic and contemporary overbank (flood) sediments. 

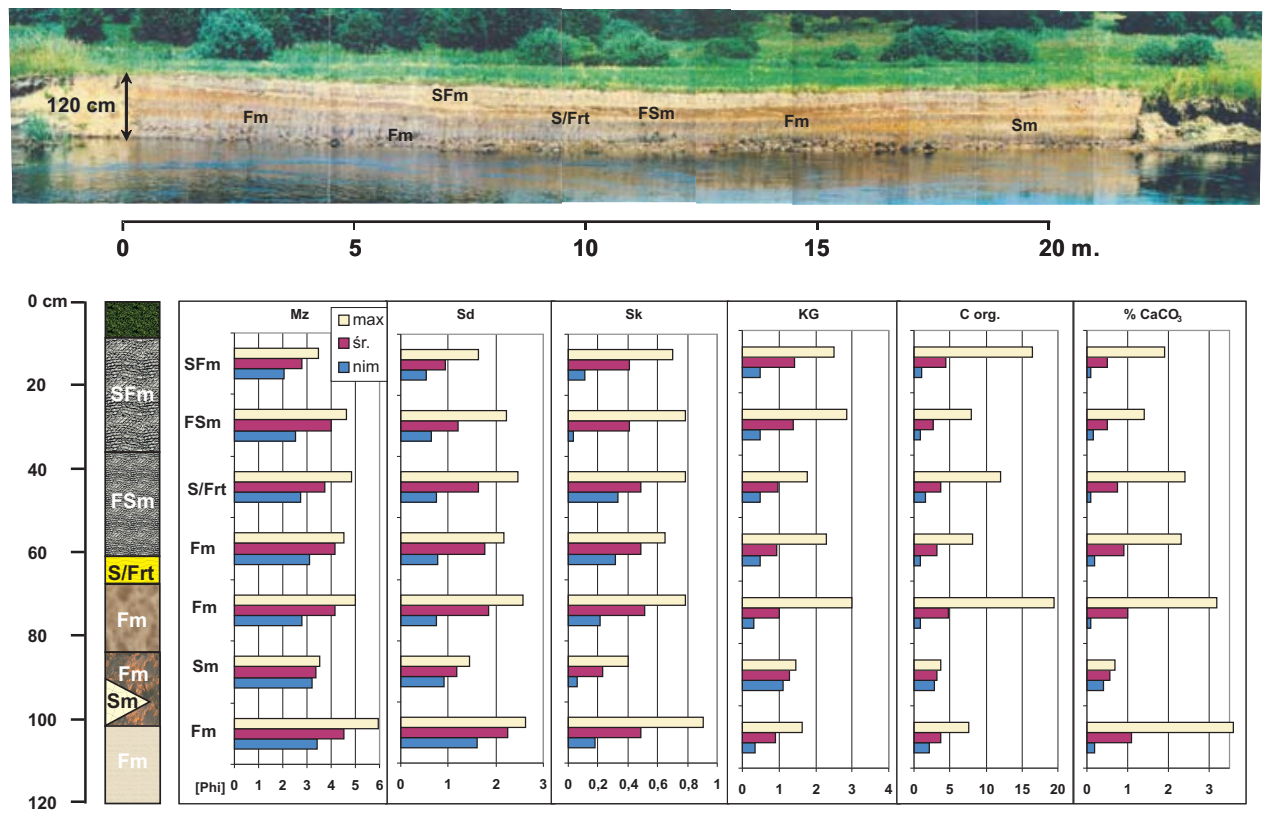

Figure 5. Exposure on the left river bank - lithological perimeters of flood basin deposits (explanations of the lithodynamic's code in the text).
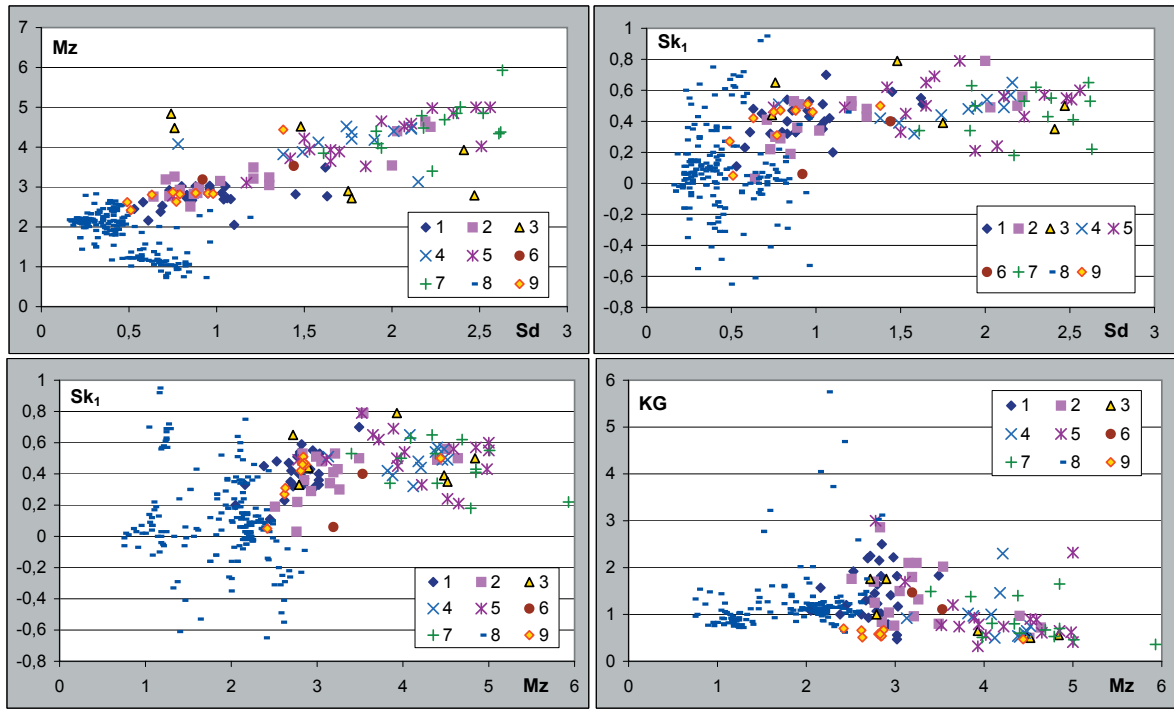

Figure 6. The relationship between different grain perimeters of the river deposits exposed on the left bank of the Wieprza; 1 - coarse sandy silt, 2 - fine sandy silt, 3 - silt interbedded by sand, 4 - clayey silt, 5 - clay with Fe intercalations, 6 - fine sand, 7 - clay, 8 - contemporary sandy bar and sandy shadow deposits, 9 - sub-fossil overbank (flood) deposits. 
support of conclusions regarding the age of subfossil overbank sediments (SFm). These are younger than the structures from the Early Mediaeval fortified site at Wrześnica.

On the graph portraying the relationship between mean grain size $(\mathrm{Mz})$ and standard deviation $(\mathrm{Sd})$, points representing slightly more coarse river channel sediments (mainly building the meander point bar) are distributed in a way that relates to the first system of Mycielska-Dowgiałło (1995), in which an increase in energy and water-flow dynamics is expressed by worsened sorting of sediments and increasing mean grain size (Fig. 3). A similar arrangement of layers is present in contemporary sandy bars and sandy shadows. The points representing sediments filling the palaeochannel and flood deposits building the top part of the floodplain are arranged in accordance with arrangement 2a after Mycielska-Dowgiałło (1995). Genetically, these deposits are overbank formations. In this case, accumulation of increasingly fine deposits takes place with gradually or suddenly decreasing energy of water flowing over the floodplain, which mainly transports suspended matter.

On the $\mathrm{Sk}_{1}-\mathrm{Mz}$ diagram, points related to fossil overbank deposits have similar positions to contemporary sandy bars and sandy shadows shifted towards larger mean grain sizes and nearly symmetrical grainsize distributions (Fig. 3). Sediments of the palaeochannel filling and of the subfossil flood cover are more fine-grained and have positively and very positively-skewed grain-size distributions, informing about a predominance of accumulative conditions.

The arrangement of points on the $\mathrm{Sk}_{1}-$ Sd diagram (Fig. 3) shows that the degree of sorting of the sediment becomes worse with a richer content of fine material than in the most frequent fraction (positively- and very positively-skewed grain-size distributions). Values of $\mathrm{Sk}_{1}>+0.1$ mainly relate to the investigated overbank sediments, suggest-

Table 1. Average and extreme water levels at gauges on the lower Wieprza River (Rocznik Hydrologiczny ... [Hydrological Yearbook of Surface Waters...]), Florek 1991

\begin{tabular}{lccccc}
\hline \multirow{2}{*}{$\begin{array}{c}\text { Water } \\
\text { level gauge }\end{array}$} & $\begin{array}{c}\text { km long } \\
\text { river }\end{array}$ & $\begin{array}{c}\text { Catchment } \\
\text { area } \\
\left(\mathrm{km}^{2}\right)\end{array}$ & Minimum (NNW) & Mean (SSW) & Maximum (WWW) \\
\cline { 4 - 6 } Sławno & 45.2 & 1283 & 8 & 58 & 230 \\
& & & $(3,10.06 .1978)$ & $(1966-1980)$ & $(6.01 .1982)$ \\
Stary Kraków & 20.6 & 1510 & 130 & 211 & 461 \\
& & & $(17,23.07 .1901)$ & $(1961-1975)$ & $(31.01 .1892)$ \\
\hline
\end{tabular}

Table 2. Average and extreme water flow at gauges on the lower Wieprza River (Rocznik Hydrologiczny ... [Hydrological Yearbook of Surface Waters...]), Florek 1991).

\begin{tabular}{lccccc}
\hline \multirow{2}{*}{$\begin{array}{c}\text { Water } \\
\text { level gauge }\end{array}$} & Minimum (NNQ) & Mean (SSQ) & Maximum (WWQ) & & \\
\cline { 2 - 4 } $\mathrm{Q}_{\max }: \mathrm{Q}_{\mathrm{av}}: \mathrm{Q}_{\min }$ & $\mathrm{Q}_{\max }: \mathrm{Q}_{\min }$ \\
\hline Sławno & 8.32 & 14.5 & 43.3 & $2.99: 1: 0.57$ & 5.2 \\
& $(14.02 .1976)$ & $(1966-1980)$ & $(11.07 .1980)$ & & \\
Stary Kraków & 5.6 & 14.7 & 63.1 & $4.29: 1: 0.38$ & 11.3 \\
& $(12 / 13.06 .1954)$ & $(1951-1975)$ & $(1.11 .1974)$ & & \\
\hline
\end{tabular}


ing that a significant decrease in or removal of floodwater energy generates conditions for accumulation with very limited participation of the sorting factor. Fossil channel sediments and sediments of the sandy bars and sandy shadows present in most of the investigated samples show a slightly better degree of sorting. The existence of such a relationship in variously-aged (fossil) channel sediments along the Wieprza has been shown by Kaczmarzyk (2004), and for present sandy bars and sandy shadows by Florek and Kaczmarzyk (2007).

The relationship between the graphic kurtosis indicator and mean grain size (Fig. 3) indicates that the uniformity of conditions of sediment accumulation grows, though only slightly, with increasing energy of water flow.

The analysed relationship diagrams indicate a clear textural distinction between fossil and sub-fossil overbank deposits and the fossil channel deposits and present flood deposits. The relationship between the older and present overbank deposits is especially interesting. The organic matter content and content of calcium carbonate are additional characteristics differentiating these deposits. In fossil and sub-fossil overbank sediments organic matter content varies between $0.1 \%$ and $20.6 \%$ (mean $2.5 \%$ ), while in contemporary deposits it is between 0 and $9.2 \%$ (mean $0.21 \%$ ). The average calcium carbonate contents in the analysed deposits are respectively $0.6 \%$ for the older and $0.11 \%$ for the present deposits. These very distinct differences between deposits attest to a distinct change in conditions for overbank sedimentation which were present from the $19^{\text {th }}$ century on, probably due to river training work (straightening and deepening of the channel). The greater similarity between present flood deposits and channel deposits results, to a large extent, from the short overbank transport, and from a deficit of sediment, in terms of both the volume of available material and the size of transported grains (Florek and Kaczmarzyk, 2007), and from the increased energy of the floods - an effect of the post-trained river cutting into the surface of the floodplain.

\section{VARIABILITY TO CHARACTERISTICS OF FLOOD BASIN DEPOSITS}

The $22 \mathrm{~m}$ outcrop on the left bank provides a relatively clear picture of the sequence of overbank deposits, which represent the filling of a flood basin. This basin is visible in the morphology of the present floodplain. It is nearly rectangular, and the outcrop in the river bank allows the arrangement of layers building its peripheral, south-eastern part to be seen. At the bottom (about $120 \mathrm{~cm}$ below the surface) there is a clay bed of $19 \mathrm{~cm}$ thickness on average. On it rests a layer of clay with iron precipitations on average $13 \mathrm{~cm}$ thick. Further upwards there are - consecutively - layers of: clayey mud $(6 \mathrm{~cm})$, fine sandy mud $(25 \mathrm{~cm})$ and coarse sandy mud $(27 \mathrm{~cm})$ This sequence of overbank deposits is clearly characterised by upper deposits becoming coarser, as confirmed by the vertical variability to mean grain sizes. This may indicate an increase in the intensity and energy of the floods, as is confirmed by accumulations of coarser material. However, a coarsening of deposited material may be caused by the supply of just such material from the areas of alimentation, which could have been subject to deforestation, or else may be due to climate change or more intense human interference in the immediate vicinity of the stretch of valley investigated.

Lithofacially, in accordance with the notation proposed by Miall $(1978,1985)$ and Zieliński (1995, 1998), two consecutive clay layers from the floor may have the symbol Fm, which offers both textural information and information on the massive structure 
of the link in the analysed profile. The iron precipitations distinguishing the upper part should be interpreted as the effect of postsedimentation processes, most probably connected with groundwater-level oscillations and penetration by roots. The massive structure of this layer indicates a situation of large volumes of floodwater, containing large amounts of uniform clay suspension, arriving in the sedimentation basin. When the energy of inflowing water dissipated or was equal to zero, good conditions for decantation of the suspension were formed in the basin.

The fine sand layer $(\mathrm{Sm})$, visible along a $4 \mathrm{~m}$ length on the right side of the outcrop (Fig. 2), and wedging into the clay layer with iron precipitates, indicates that the described conditions of sedimentation were disturbed by water pouring in with higher energy and dynamics. At the same time it supplied coarser material. However, this was deposited only in the edge parts of the sedimentation basin. It is worth observing that this fine sand material, with respect to grain-size characteristics, corresponds with younger (higher-lying) layers of flood deposits, and therefore with present-day overbank alluvia.

Above the Fm layer there is a layer of clayey mud of massive structure. In the lithofacial code, clayey and muddy deposits are designated by the same textural abbreviation $\mathrm{F}$. The clayey mud layer showing massive structure should also therefore take the symbol Fm. Conditions of sedimentation were similar to those described for the generation of the clay layer, albeit with the small difference in grain size indicating a slightly higher energy of overbank flow, supplying material to the flood basin.

Lying above the thin layer is a mud series with fine sand laminations formed as an S/Frt lithofacies (see J. Szmańda 2006). An interpretation of the generation of this is offered in an analysis of the right bank out- crop. However, in that outcrop it is formed differently and is an element filling the palaeomeander encircling the Early Medieval fortified site (see Figs. 2 and 5).

The next two layers highest in the profile are built of fine sandy mud (FSm) and coarse sandy mud (FSm). In order to distinguish between the symbols of the lithofacial codes of these rather similar layers, it is proposed that the name and symbol of the latter be changed to mud sand (SFm). This change is justified by slightly larger grain size and slightly higher (but macroscopically visible) organic matter content. The symbol of massive structure is proposed for both lithofacies, but it is worth signalling that these are not fully uniform. In the FSm lithofacies there is an interbedding in the form of a thin, non-continuous and probably post-sedimentary disturbed lamination of very fine sand. This is proof of an incident of distinct energy growth of water flowing into the flood basin during an already ongoing flood. In turn, in lithofacies SFm, there are very weakly-marked, nearly horizontal streaks, indicating local enrichment with organic matter. in line with the means of formation of the above structures, the authors propose that the description "massive structure" be left unchanged.

Lithofacies FSm and SFm record the fact of further growth of energy and dynamics of the flood waters. The relatively large thickness of each of the lithofacies may on one hand indicate a high content of suspensions in the floodwaters, and on the other the duration of the flood events, of which at least some progressed in a complex way, consisting in a rise and lowering of water level during a single flood.

In the diagram for the $\mathrm{Mz}-\mathrm{Sd}$ relationship (Fig. 3), points representing overbank deposits of the flood basin are distributed characteristically for system $2 \mathrm{a}$ after Mycielska-Dowgiałło (1995), wherein the degree of sorting decreases with decreasing 
mean grain size. The 2 a system i.a. indicates an environment with periodic supply of badly-sorted material transported in suspension. In the same diagram, the position of points representing deposits of presentday sandy bars and sandy shadows corresponds to more coarse and worse-sorted sediments. Their distribution suggests the first system as described by MycielskaDowgiałło (1995), in which the degree of sorting decreases with growing mean grain size. This is a system indicating an environment with variable dynamics and forces transporting the sediments. Periods with low flow dynamics, in which sorting and transport by saltation are predominant, have been separated by periods of short-duration increased flow, which, as it weakens, ensures a predominance of accumulation. This relationship is characteristic for fluvial deposits of the channel facies, and indicates weak transforming of contemporary flood deposits, for which the direct sources of alimentation are the sediments of the river channel (transported therein and subjected to its hydrodynamic regime), (Florek and Kaczmarzyk, 2007).

The $\mathrm{Sk}_{1}-\mathrm{Mz}$ diagram shows that, within the interval of fractions these represent, fossil and sub-fossil deposits of the flood basin show positively and very positively skewed values for graphic skewness (Fig. 6). This asymmetry of grain-size distributions allows for the observation in the deposits investigated of a prevalence of finer grains in relation to grains of maximum frequency, and therefore a predominance of accumulation trends in the analysed deposition environment. Distinctly different positions are taken in the diagram by points representing contemporary flood deposits. They are shifted towards the coarser fractions, and are distributed rather symmetrically with respect to zero on the graphic skewness axis. A great part of these represent nearly-symmetrical grain-size distributions, in this respect quite similar to the fossil and present channel sediments of the Wieprza (Kaczmarzyk, 2004).

The $\mathrm{Sk}_{1}-\mathrm{Sd}$ relationship indicates that deposits of the flood basin, while representing a narrow range of graphic skewness values, assume rather diverse values for standard deviation (from moderate to very weak sorting). Present flood deposits have a wide range of graphic skewness values (from very negatively to very positively skewed), and the degree of sorting varies across a narrower range (between very good and medium sorting). Conditions for accumulation under which the sediments of the flood basin were deposited were not therefore favourable to grain-sorting processes. The fineness of the deposits shows that accumulation proceeded mainly via suspension, but decantation could have been impeded and slowed by mixing of water in the shallow flood basin, e.g. under wind action. Such progressing accumulation may explain weaker sorting of the deposits.

On the KG-Mz diagram, points representing the deposits of the flood basin indicate the presence of a rather distinct relationship, expressed in lower graphic kurtosis values with a decrease in mean grain size. The lithofacies SFm, FSm and S/Frt have a prevalence of grain-size distributions with sharp and high and very high peaks (more uniform conditions of sediment deposition). In the remaining, more fine-grained lithofacies, grain-size distributions with distinct and gentle, wide peaks (variable conditions of deposition) are characteristic.

\section{CONCLUSIONS}

The lithofacial and textural similarity between the two top layers in the outcrop on the right bank (flood basin) and the layer of sub-fossil flood deposits on the left bank (warp soil layer), supports the conclusion 
that these deposits were generated synchronously, after the timber structures of the Early Medieval fortified site were built. These deposits indicate that, during the last thousand years (up to the time of river training work in the first half of the $20^{\text {th }}$ century) there were many floods of relatively low energy. Changes in the lithological characteristics of flood deposits indicate a gradual increase in flood energy, which was mainly the result of natural processes. However, after river training work entailing a straightening and deepening of the channel, river slope increased, water flow grew and the river bed cut into the surface of the floodplain. In consequence, floods and accompanying processes, including overbank sedimentation, were of a markedly different nature. The Wieprza now spills over into the floodplain less often, but banks are topped with higher dynamics. Erosion in the nearbottom parts of the river channel washes out and brings under transportation more coarse material, building the floor part of the floodplain. Such sediments, transported and formed in the hydrodynamic regime of the river channel, are mainly accumulated on its banks. Accumulation in areas of the floodplain further from the river channel is limited to the generation of thin (millimetre-thick) coatings.

\section{REFERENCES}

Biernat, B. (1977a), Typowe okresy występowania wezbrań [Typical periods of flood occurrences], Gazeta Obserwatora $I M i G W 11$.

Biernat, B. (1977b) Typowe okresy występowania niżówek [Typical periods of low water occurrences] Gazeta Obserwatora IMiGW 12.

Cyberski, J. (1984), Zasoby wodne zlewni rzecznych [Water resources of the river basins], in B. Augustowski (ed.),
Pobrzeże Pomorskie [The Pomeranian Coastal Region], Ossolineum, Gdańsk, 189-213.

Dynowska, I. (1971), Typy reżimów rzecznych w Polsce [Types of the river regimes in Poland], Zeszyty Naukowe UJ, Prace Geograficzne 28, Kraków.

Florek, E., Florek, W., Kaczmarzyk, J. (1998), Studia nad paleohydrologicznymi zmianami koryta Wieprzy i jej równi zalewowej w okresie subatlantyckim w kontekście funkcjonowania wczesnośredniowiecznego grodziska we Wrześnicy [Studies on the palaeohydrological changes of the Wieprza River and its floodplain in the Subatlantic Period in the context of functioning of the early medieval fortified site in Wrześnica], Acta Archaeologica Pomoranica, 1, Szczecin, 185-194.

Florek, W. (1991), Postglacjalny rozwój dolin rzek środkowej części północnego skłonu Pomorza [Postglacial development of the river valleys in the middle part of the northern slope of the Pomerania], Wyższa Szkoła Pedagogiczna w Słupsku, Słupsk.

Florek, W., Kaczmarzyk, J. (2007), Wspótczesne formy i osady wezbraniowe Wieprzy na odcinku Staniewice - Kowalewice [Contemporary alluvial forms and sediments of the Wieprza River (Northern Poland) at the Staniewice-Kowalewice section], in R. Sołtysik (ed.), Systemy dolinne i ich funkcjonowanie [The Valley systems and their functioning], Prace Instytutu Geografii Akademii Świętokrzyskiej w Kielcach, Akademia Świętokrzyska, No. 16, Kielce, 205-213..

Florek, W., Nadaczna, E. (1986), Zmiany biegu Parsęty i Wieprzy w ciaggu ostatnich dwustu lat w świetle analizy materiałów kartograficznych [Changes in the course of the Parsęta and Wieprza rivers, Northern Pomerania (Poland), in the last 200 years in the light of cartographic ma- 
terial analysis], Badania Fizjograficzne nad Polska Zachodnia, 36A, 33-52.

Kaczmarzyk, J. (2004), Holoceńska paleohydrologia środkowej Wieprzy w świetle cech sedymentologicznych osadów korytowych [Paleohydrology of the Middle Wieprza River in Holocene in the light of features of particle-size parameters of its channel sediments], Prace Geograficzne 200, Instytut Geografii i Przestrzennego Zagospodarowania (IGiPZ) PAN: 119145.

Miall, A. D. (1978), Lithofacies types and vertical profile models in braided river deposits: a summary, in A.D. Miall (ed.), Fluvial sedimentology, Canadian Society of Petroleum Geologists, Memoire, 5, 597-604.

Miall, A.D. (1985), Architectural-element analysis: a new method of facies analysis applied to fluvial deposits, Earth-Science Reviews 22, Amsterdam: 261-308.

Mycielska-Dowgiałło, E. (1995), Wybrane cechy teksturalne osadów i ich wartość interpretacyjna [Selected textural features of deposits and their interpretation value], in E. Mycielska-Dowgiałło, J. Rutkowski (eds.), Badania osadów czwartorzędowych. Wybrane metody $i$ interpretacja wyników [Research studies of Quaternary sediments. Some methods and interpretation of the results], Wydział Geografii i Studiów Regionalnych Uniwersytetu Warszawskiego, Warszawa, 29-105.

Rączkowski, W., Sikorski, A. (1996), Datowanie grodziska wczesnośredniowiecznego we Wrześnicy, gmina Sławno, stanowisko 7 [The dating of the Early Medieval fortified settlement at Wrześnica, the Sławno commune, site 7], Geochronometria 14: 169-181.
Rocznik Hydrologiczny Wód Powierzchniowych. Dorzecze Odry i rzek Przymorza pomiędzy Odra $i$ Wista, rok 1983 (i starsze) [Hydrological Yearbook of Surface Waters. The Odra River's catchment as well as the catchments of the rivers lying between the Odra and the Vistula Rivers, as of 1983 (and earlier)], Instytut Meteorologii i Gospodarki Wodnej (IMGW), Warszawa.

Szmańda, J. (2006), Rytmika powodziowa w aluwiach pozakorytowych Wisły, Drwęcy i Tążyny [Flood occurrence rhytmicity in the flood alluvia of the Vistula, Drwęca and Tążyna rivers], in: 55 Zjazd PTG, Toruń. Przewodnik sesji terenowej [55th Congress of the Polish Geological Society. Field study guidebook], Torun, 266-270

Zieliński, T. (1995), Kod litofacjalny i litogenetyczny - konstrukcja i zastosowanie [Lithofacies and genetic codes: construction and application], in E. MycielskaDowgiałło, J. Rutkowski (eds.), Badania osadów czwartorzędowych. Wybrane metody i interpretacja wyników [Research studies of the Quaternary sediments. Some methods and interpretation of the results], Wydział Geografii i Studiów Regionalnych Uniwersytetu Warszawskiego, Warszawa, 220-234.

Zieliński, T. (1998), Litofacjalna identyfikacja osadów rzecznych [Lithofacial identification of alluvial sediments)], in E. Mycielska-Dowgiałło (ed.), Struktury sedymentacyjne $w$ osadach czwartorzedowych $i$ ich wartość interpretacyjna [Sedimentological and postsedimentological structures in Quaternary sediments and their value for interpretation], Wydział Geografii i Studiów Regionalnych Uniwersytetu Warszawskiego, Warszawa, 195-257. 